Maja Klun - Jože Benčina - Lan Umek

\title{
Online költségvetési átláthatósági mutató és annak meghatározó tényezői a szlovén önkormányzatoknál
}

\begin{abstract}
ÖsszefoglaLó: A tanulmány az online helyi költségvetési átláthatóságot értékeli (OLBT) az összes szlovén önkormányzat esetében, illetve a különböző tényezók átláthatóságra gyakorolt hatását elemzi. Az önkormányzatok többsége megfelel az előirásoknak. 91 különböző jellemző átlagértékeinek összehasonlítása azt mutatja, hogy azok az önkormányzatok, amelyek nem felelnek meg a szabályozásnak, általában kisebbek, gyengébb az oktatási struktúrájuk, valamint az ott élők társadalmi helyzete alacsonyabb. Számos önkormányzat a jogszabályi követelményekben előirtakat meghaladó költségvetési átláthatóságot biztosít. Ezek kisebb méretúek és kevésbé vagyonosak, mint más, a szabályozásnak megfelelő önkormányzatok. Mindkét jelenséget az ügynök- és a legitimitáselmélet alapján magyarázzuk. ${ }^{1}$
\end{abstract}

\section{Kulcsszavak: helyi költségvetés, fiskális átláthatóság, Szlovénia}

JEL-KóD: E6

DOl: https://doi.org/10.35551/PSZ_2019_3_5

A közpénzek elköltésének átláthatósága számottevő érdeklődésre tett szert, és kiterjedt kutatások tárgya lett, amelyek a különböző tényezők átláthatóságra gyakorolt hatását vizsgálják és fordítva. A nagyobb költségvetési átláthatóság célja, hogy lehetővé tegyék a közpénzek hatékonyabb felhasználását és a közpolitika végrehajtását. Az átláthatóság fó célja, hogy a nyilvánosság hozzáférhessen az államháztartáshoz kapcsolódó információkhoz, és így nagyobb lehetősége legyen az állami kiadá-

Levelezési e-cim: joze.bencina@fu.uni-lj.si maja.klun@fu.uni-lj.si lan.umek@fu.uni-lj.si sokkal és az állami bevételekkel kapcsolatos döntéseket befolyásolni. Caamano-Alegre et al. (2013) a következőképpen magyarázták a költségvetési átláthatóságot: „... az állami költségvetés-tervezés, valamint a piaci követelmények, a civil társadalom igényei és a polgárok részvétele közötti kapcsolatot elösegitö eszköz".

A szakirodalomban számos eltérő megközelítés található a költségvetési átláthatóság mérése kapcsán. Néhány megközelítés kérdőíveket használ, míg mások a nyilvánosság számára hozzáférhető információkat követik nyomon. A Nemzetközi Költségvetési Partnerség (International Budget Partnership - IBP) egy öszszetett kérdőívet használ (például IBP, 2013) 
a nemzeti költségvetési átláthatósági mutató mérésére a világ legtöbb országában. Úgy döntöttünk, hogy kutatásunkban az Ott et al. (2014) által meghatározott módszertant alkalmazzuk, amely alapján ellenőriztük minden egyes szlovén önkormányzat weboldalát, hogy nyomon követhessük az online elérhető költségvetési dokumentumokat.

$\mathrm{Az}$ átláthatóság mérésére vonatkozó kutatásokon túlmenően fellelhetők az átláthatóságot és az átláthatóság különböző hatásait magyarázó különféle tanulmányok. A magyarázatok általában a megbízó-ügynök-elméleten (Ferejohn, 1986; Barro, 1973), valamint a legitimitáselméleten (Weber, 1978 és Suchman, 1995) alapszanak. Alesina és Perotti (1996) felveti a „fiskális illúzió” elméletét is. Mint azt már említettük, más tanulmányok az átláthatóság hatásaira összpontosítottak, különösen a fiskális fegyelemre, a közpénzek elosztásának hatékonyságára, a felelősségvállalásra, a korrupcióra stb. (Alesina, Perotti, 1996; Hameed, 2005; Wehner, Renzio, 2013). A nagyobb átláthatóság javítja a fiskális fegyelmet és a közpénzek elosztásának hatékonyságát, valamint csökkenti a korrupciót. A számos pozitív hatás ellenére, amelyeket különböző kutatások során vizsgáltak, Peisakhin és Pinto (2010) úgy érvelt, hogy az átláthatóságnak vannak árnyoldalai is, például költségvetési botrányok.

Kutatásunk legalább két ponton kiegészíti a különböző tanulmányokat. Először is: ismertetjük a szlovén helyi költségvetési átláthatóság első mérését. Ezidáig Szlovéniában nem került sor a helyi költségvetés átláthatóságának ilyen átfogó tanulmányozására. Másodszor, a helyi közösségek átláthatósága szintjén a kutatás kiegészíti a meglévő szakirodalmat a magyarázó változók mérése terén.

A kutatás alapvető kérdése az, hogy a költségvetési dokumentumok átláthatóságának eltérő szintjeit mutató önkormányzatok miben különböznek egymástól. Más szóval: az ügynökök milyen ösztönzők vagy külső nyomás hatására alakítják ki a lehetséges átláthatósági intézkedések bizonyos szintjét. Ebből a ponttól kiindulva két konkrét kérdést fogalmazunk meg.

Mi idézi azt elő, hogy az önkormányzatok nem felelnek meg a szabályozásnak?

- Mi idézi azt elő, hogy az önkormányzatok a kutatásunkban megfigyelt legmagasabb szintű költségvetési átláthatóságot valósítják meg?

A kérdések megválaszolásához meghatároztunk egy modellt, amely az önkormányzatok csoportjainak összehasonlítására szolgál. Ezért összehasonlítottuk az átláthatóság biztosítása terén különböző magatartást tanúsító önkormányzatok csoportjait, és tanulmányoztuk a csoportpárok közötti különbségeket. 91 költségvetési, politikai, szociodemográfiai és szociogazdasági mutatót vizsgáltunk. Ezeket a korábbi kutatások alapján választottuk ki, és a már említett magyarázó elméleteket követve továbbiakat is belevettünk a kutatásunkba.

A jelen kutatás kiegészíti más olyan szerzők megállapításait, akik hasonló mutatókat használtak, és elemezték azoknak az átláthatóságra gyakorolt hatását. Ezen túlmenően néhány új kérdést is felvet az átláthatóság biztosítása terén az önkormányzatok magatartását meghatározó tényezők kapcsán.

A cikk felépítése a következő: a szakirodalmi áttekintést tartalmazó fejezetet a módszertan és a kutatás eredményeinek ismertetése követi, a hasonló kutatások megállapításaival történő összehasonlítással egyetemben. A következtetés magában foglalja a megállapítások összefoglalását és a jövőbeli kutatások kihívásait.

\section{A KÖLTSÉGVETÉSI ÁTLÁTHATÓSÁG MÉRÉSEI ÉS AZ AZT MEGHATÁROZÓ TÉNYEZÓKK}

Az átláthatóság egy nagyon tág fogalom. Általában az információk rendelkezésre állásához köthető. Esteves de Araujo és Tejedo-Romero 
(2016) az „információk elérhetőségét” kínálati oldali átláthatóságként definiálta, szemben a keresleti oldal átláthatóságával, amelyet ezen információknak a különböző érdekeltek általi felhasználhatóságaként határoztak meg. Heald (2006) rámutatott, hogy az átláthatóság a jó kormányzást elősegítő tényező. A nyilvánosság számára hozzáférhető információknak időszerűnek, megbízhatónak, közérthetőnek és átfogónak kell lenniük (Kopits, Craig, 1998). Az OECD (2001, 7. oldal) azt is hozzáteszi továbbá, hogy a költségvetési átláthatóság „az összes releváns költségvetési információ maradéktalan, idöszerü és rendszeres közétételét" jelenti. A Nemzetközi Valutaalap (IMF) a fiskális átláthatóságról szóló kézikönyvében (2007) megállapította, hogy a fiskális átláthatóság magában foglalja a fiskális politika szándékait, az állami szektor számadásait és a költségvetési előrejelzéseket. Jordan et al. (2017) szintén rámutatott a közérthető beszámolók fontosságára, mivel az éves pénzügyi beszámolók túlságosan átfogóak lehetnek ahhoz, hogy a nagyközönség megértse azokat. Esteller-More és PoloOtero (2012, 1156. oldal) így összegezték a különböző fogalommeghatározásokat: „a fiskális átláthatóság azzal jár, hogy egy kormány nemcsak a jelenlegi költségvetési tevékenységéröl nyüjt részletes tájékoztatást, hanem jövöbeli elörejelzéseiröl és a múltbeli teljesitményéröl is... és hogy ennek a tájékoztatásnak könnyen elérhetönek (például az interneten ingyenesen hozzáférhetönek) kell lennie”. Különböző szerzők (Heeks, 2005; Kraemer és King, 2006; Alcaide-Muñoz és Rodríguez-Bolívar, 2015) elismerték az infokommunikációs technológiáknak (ikt-k) a fiskális átláthatóságot javító eszközökként való felhasználását.

A költségvetés átláthatóságának megfigyelését nemzeti szinten több intézmény végzi, nevezetesen az OECD munkacsoportja, az Európai Unió és a már említett IBP. A nemzeti költségvetések nyitottságára vonat- kozó információk rendelkezésre állása alapján számos tanulmány készült a nemzeti költségvetések átláthatóságáról (például Alesina és Perotti, 1996; Alesina et al., 1999; Bastida és Benito, 2007; Wehner és Renzio, 2013). Mivel a költségvetési átláthatóságra nincs egyetlen közös fogalommeghatározás, nem létezik egységes mérési módszertan sem. Ennek ellenére számos javaslat és mérés létezik, amelyek közül néhányat már említettünk. Az OECD (2002) ismerteti a költségvetési átláthatóság jó gyakorlatait, a Nemzetközi Valutaalap (IMF, 2014) bevezette a fiskális átláthatósági kódexet, és az IBP egy kérdőív segítségével (IBP, 2013) méri a nyitott költségvetéseket. Mindezek a javaslatok jó alapul szolgálhatnak a fiskális vagy költségvetési átláthatóság nyitottságának mérésére szolgáló alaptényezők összeállításához. Ez számos különböző mérést és kérdőívet eredményezett, amely a költségvetési átláthatósági mutató kiszámításához vezetett (Tekeng és Sharaf, 2015; Bolívar, Pérez és López-Hernández, 2013; Jarmuzek et al., 2009; Bastida és Benito, 2007).

A helyi költségvetés átláthatóságát mérő tanulmányok kevésbé gyakoriak. Kroth (2012) szintén rámutat arra, hogy nem létezik egységes módszertan a helyi fiskális átláthatóság mérésére, mivel azt nehezebb meghatározni, fóként azért, mivel ez a helyi feltételek ismeretének beépítését igényli. Guillamón et al. (2011) azt is hangsúlyozták, hogy a szubnacionális (nemzeti szint alatti, azaz helyi, regionális) szinten történő mérés összetettebb. 2012-ben az IBP tíz kísérleti tanulmány elemzését végezte el a helyi költségvetések területén. Ez a cikk azt is állítja, hogy nagyon kevés tanulmány foglalkozik a helyi önkormányzatok témakörével. Mindazonáltal az elmúlt évtizedben már felbukkant a szakirodalomban a helyi költségvetési átláthatóság megállapításával kapcsolatos néhány kutatás. Beales és Thompson (2010) 134 helyi egységen végzett kutatásokat az egyesült államokbeli Virginiában. 16 kritéri- 
um alapján ellenőrizték az információk elérhetőségét az interneten. Más szerzők (Boubeta, Santias és Alegre, 2010; Caamano, Alegre et al., 2011, Caamano, Alegre et al., 2013) egy autonóm spanyolországi közösség (Galícia) önkormányzatainak költségvetési átláthatóságát vizsgálták. Rodríguez-Bolivar et al. (2013) spanyol önkormányzatok átláthatóságát vizsgálta. A Nemzetközi Valutaalap (IMF) módszertanát alkalmazták. Az IBP módszertanának segítségével Kroth (2012) számos dél-amerikai ország, valamint India, Malajzia, Mongólia és Mali elemzését készítette el. Lawson és Alvarez (2013) az IBP módszertanát használták a helyi költségvetés átláthatóságának értékelésére Bali, Indonézia és Tanzánia esetében. $M a$ és Wu (2011) különböző forrásokat használtak ahhoz, hogy 31 kínai tartomány fiskális átláthatóságát meghatározzák. Ott et al. (2014), azt ellenőrizték, hogy a horvátországi helyi közösségek weboldalain rendelkezésre állnak-e költségvetési dokumentumok. A horvátországi tanulmányhoz hasonlóan, mi is a weboldalak áttekintésével hajtottuk végre a helyi költségvetési átláthatóság értékelését. Hasonló módszertant alkalmaztak például a Cseh Köztársaság (Sedmihradská, 2015) és Románia (Pintea et al., 2013; Pintea, 2014) egyes kiválasztott régiói, valamint az USA egyes kiválasztott városai (Styles és Tennyson, 2007) esetében. Kutatásunkban ugyanazt a módszertant alkalmaztuk, mint Ott et al. (2014). Megvizsgáltuk az összes szlovén önkormányzat honlapját, és ellenőriztük a kiválasztott költségvetési dokumentumok rendelkezésre állását. A módszertant részletesebben a módszertani fejezet ismerteti.

Számos kutató vizsgálta különböző tényezőknek a költségvetési átláthatóságra gyakorolt hatását. A különböző kutatások szerint az átláthatóságot meghatározó tényezők mögött húzódó leggyakoribb elméletek:

- az ügynökelmélet (avagy megbízó-ügynök-elmélet),
- a neoinstitucionalista elmélet,

- a legitimitáselmélet, valamint

- a fiskális illúzió elmélete.

Az ügynökelmélet fö alapelve az, hogy az állami vezetők érdekei nem esnek egybe az állampolgárok érdekeivel, és ezért az információk közzétételével elszámoltathatóbbá válnak a döntéseikért (Alt et al., 2001; Jensen és Meckling, 1976; Fama, 1980; Ferejohn, 1986; Barro, 1973). Ügynökként a választott tisztviselőknek az őket megválasztó nép érdekében kellene eljárniuk. Mivel a polgárok nem biztosak a választott tisztviselők cselekedeteiben, információs aszimmetria következik be. A jobb átláthatóság javít az információhiányon, és így az érdekeltek tájékozódhatnak az állami vezetők intézkedéseiről. Ez növeli a hatékonyságot és a bizalmat, és így mérsékeli a megbízó-ügynök-problematikát. RodríguezBolívar et al. (2013) az ügynökelmélet mellett megemlítette a neoinstitucionalista elméletet is, amely az innovációknak a vezetői számvitel terén történő átvételét magyarázza. A neoinstitucionalista elmélet szerint a külső érdekeltek arra ösztönzik a szervezeteket, hogy legitim és társadalmilag elfogadható intézkedéseket hozzanak (Meyer és Rowan, 1977; Scott, 1987; Powel és DiMaggio, 1991). A legitimitáselmélet szerint a közhivatalnokok azért akarnak a munkájukkal kapcsolatos információkat nyilvánosságra hozni, hogy előmozdítsák a szervezeti legitimitást, és javítsák a közszféra intézkedéseibe vetett bizalmat. Ezért az átláthatóság javítja a politikai döntések közmegítélését, és legitimebbé teszi azokat (Heald, 2006; De Fine Licht et al., 2011). A megbízó-ügynök-elmélettel összhangban, a fiskális illúzió elmélete is rámutat arra, hogy a választott tisztviselőket nem ösztönzik az átláthatóságra. Alesina és Perotti (1996) kifejtették, hogy a fiskális illúzió elmélete azon a felfogáson alapul, miszerint az állampolgár (adófizető) nem képes értékelni az állami programok teljes költségét. Továbbá a 
fiskális illúzió forrásait más empirikus kutatásokban is ismertették (például Oates, 1991; Heyndels és Smolders, 1994). A fiskális átláthatóság felülkerekedik a fiskális illúzió problémáján, mivel az állampolgároknak több információ áll rendelkezésre, és ily módon csökken az alulbecsült költségek és az állami kiadások túlbecsült előnyeinek illúziója.

Az említett elméletekkel összhangban, a különböző kutatások kiterjednek a politikai tényezők (például a hivatalnokok ideológiája, a politikai pártok tényleges száma, koalíciós kormányok és politikai részvételük), a gazdasági tényezők (például egy főre jutó GDP, helyi adósság, kiadások), valamint a szociokulturális tényezők (például népesség mérete, munkanélküliségi ráta) hatásainak értékelésére is (Albalate del Sol, 2013). Ezért nehéz az áttekintő kutatáson alapuló kutatási eredmények közvetlen összehasonlítása. A felsoroltak ellenére a legtöbb kutatási eredményből leszürhető néhány olyan hatás, amely a leggyakrabban bizonyult fontosnak. A kutatás eredményei azt mutatják, hogy a lakosok száma pozitív hatással van a költségvetés átláthatóságára (például Styles és Tennyson, 2007; Caamano-Alegre et al., 2011). A magasabb fejlettségi szint vagy a magasabb egy före jutó jövedelem szintén pozitív hatással van (Giroux és McLelland, 2003). A kutatások nagy része a helyi adósság tekintetében nem tárt fel jelentős hatást (Sedmihradska és Haas, 2013; CaamanoAlegre et al., 2013; ${ }^{2}$ Gerunov, 2016).

A mi kutatásunk abban tér el az egyéb tanulmányoktól, hogy magában foglalja az önkormányzatok magatartásának elemzését is, a jogszabályi követelmények teljesítését jelző mutatót elérō, valamint el nem érő kategóriákba csoportosítva azokat, és értékeli az említett tényezők hatását. A jelen tanulmányban szereplő mutatók három fö kategóriába sorolhatók: gazdasági, demográfiai és társadalmi. E mutatók átlagos értékeit az elért mutató alapján hasonlítjuk össze.

\section{MÓDSZERTAN}

Ez a cikk a szlovén helyi költségvetési átláthatósági mutató első értékelésének eredményeit mutatja be. Az Ott et al. (2014) által megvalósított módszertant használtuk. Amint azt már kifejtettük, a weboldalak áttekintését számos más tanulmányban is használták az átláthatóság meghatározására (Kadunc, 2016; Sedmihradská, 2015; Pintea et al., 2013; Styles és Tennyson, 2007). Az IMF, az OECD és az IBP méréseitől abban tértünk el, hogy mi azok aktuális állapotában ellenőriztük a dokumentumok rendelkezésre állását, mivel az említett mérések a fiskális átláthatósághoz kapcsolódó számos kérdésben (például világos fiskális fejlesztési stratégia) szakértők körében végzett felméréseket használnak, és nem csak magát a költségvetést. A legtöbb esetben az említett eszköztárak a központi kormányzatok számára készülnek, és egyes részek nem vonatkoznak a helyi költségvetési átláthatóságra. Úgy döntöttünk, hogy az átláthatóságot úgy mérjük, hogy egyes kiválasztott költségvetési dokumentumok a nagyközönség rendelkezésére állnak-e. A mutató meghatározásának fó célja annak ellenőrzése, hogy az önkormányzatok weboldalain milyen költségvetéssel kapcsolatos dokumentumok vannak közzétéve. A mutatót tehát az önkormányzatok weboldalainak áttekintésével határoztuk meg, megállapítva, hogy a költségvetéssel kapcsolatos dokumentumok a nyilvánosság számára hozzáférhetők-e. A jelen tanulmányban az alábbi dokumentumok közzétételét vizsgáltuk (1. táblázat):

A szabályozás szerint a következő dokumentumok közzététele szükséges: költségvetési javaslat, elfogadott költségvetés és a költségvetésre vonatkozó év végi beszámoló (Államháztartási törvény - JF UPB4, a Szlovén Köztársaság Hivatalos Lapja, 14/13. szám, 2013. február 15.), ami azt jelenti, hogy legalább az OLBT 1., 2. és 4. (1. táblázat) dokumentumokat közzétevő önkormányzatok fe- 


\section{ONLINE HELYI KÖLTSÉGVETÉSI ÁTLÁTHATÓSÁG (OLBT)}

\begin{tabular}{|l|l}
\hline Költségvetési javaslat & $\begin{array}{l}\text { Egy önkormányzat honlapján szereplő bármely olyan dokumentum, amelynek } \\
\text { címében szerepel a költségvetési javaslat vagy tervezet kifejezés, függetlenül attól, } \\
\text { hogy ezt önállóan vagy egy ülés során mérlegelendő dokumentáció részeként } \\
\text { teszik-e közzé. }\end{array}$ \\
\hline Elfogadott költségvetés & $\begin{array}{l}\text { Az elfogadott költségvetésről szóló rendelet; csak maga az elfogadott költségvetés } \\
\text { egy dokumentum formájában; vagy egy helyi hivatalos lapban vagy helyi újságban } \\
\text { közzétett elfogadott költségvetés. A feltétel az, hogy a dokumentum az önkormányzat } \\
\text { honlapján legyen közzé téve (például egy hivatalos lap vagy újság részeként). Ha a } \\
\text { költségvetést nem fogadták el időben, az ideiglenes finanszírozásról szóló rendelet is } \\
\text { figyelembe vehető. Ha az elfogadott költségvetést egy olyan másik weboldalra mutató } \\
\text { link formájában teszik közzé, amely például önkormányzatok nyilvános információit } \\
\text { hozza nyilvánosságra, akkor úgy tekintendő, hogy a dokumentum nem elérhető az } \\
\text { önkormányzat honlapján. }\end{array}$ \\
\hline Egy dokumentumot akkor tekintünk közzétettnek, ha azt külön vagy az önkormányzati \\
\hline Aanácsi ülés dokumentációjának részeként teszik közzé, és a dokumentum címéből \\
\hline szóló évközi beszámoló \\
egyértelműen kitűnik, hogy az egy évközi beszámoló. \\
költségvetés
\end{tabular}

Forrás: saját szerkesztés

lelnek meg a szabályozásnak. Az átláthatóság minden aspektusa két további dokumentumot foglal magában, a költségvetés végrehajtásáról szóló évközi beszámolót, és az állampolgároknak szóló költségvetést (OLBT 3. és 5. pont, 1. táblázat).

Az önkormányzatok weboldalait a jogszabályban meghatározott feltételek szerint ellenőriztük. A 2015/2016-os mutató meghatározásához a decembertől áprilisig tartó időszakot vizsgáltuk, és ellenőriztük, hogy a 2015-ös évközi beszámolót, a 2016-os költségvetési javaslatot, a 2016-os elfogadott költségvetést, valamint a 2015-ös költségvetési javaslatra vonatkozó zárszámadást közzétették-e. Ugyanakkor ellenőriztük, hogy az állampolgárok- nak szóló költségvetés szerepel-e a weboldalon. Ezen dokumentumok mindegyikének jelenléte egy pontot ad hozzá a végső mutatóhoz. $\mathrm{Ha}$ az összes megnevezett dokumentum közzé van téve az önkormányzat honlapján, az önkormányzat 5-ös mutatót kap. Az átláthatósági mutató kiszámításával a helyi közösségeket az átláthatóság biztosításához való viszonyuk szerint osztályoztuk.

A kutatás második lépésének célja a különböző átláthatósági szintet biztosító helyi közösségek közötti különbségek feltárása volt. Annak meghatározására, hogy az önkormányzatoknak az információ átláthatóságával kapcsolatos magatartását főleg intézményi tényezők befolyásolják-e, illetve a környezeti hatás 
bír-e nagyobb jelentőséggel, a tényezőváltozók besorolását mérlegeltük a következő két fő csoportba: intézményi tényezők és környezeti tényezők (Muñoz és Bolívar, 2015).

E megközelítés mentén egy másik hasonló, az információ átláthatóságát ösztönző tényezőkre összpontosító besorolást is mérlegeltünk, amely négy perspektívát vesz figyelembe (Ma és Wu, 2011): a környezeti hatás helyszínén a külső igényt kifejező perspektívát, valamint az intézményi tényezőket (fiskális teljesítmény, erőforrások és kapacitás, stratégiai vezetés) kifejező három perspektívát.

Végül, hogy megőrizzük a némileg jobban makroökonómiai szemléletet alkalmazó többi tanulmány többségével való kompatibilitást, a változók négy osztályát vettük figyelembe (Sol, 2013): a fiskális, az intézményi és politikai, a szociodemográfiai és a gazdasági kontextus változóit, és az adatmodellben megadtuk a szociodemográfiai osztályt. Az adatmodell szerkezetét a 2. táblázat ismerteti.

Az említett elméleteket, valamint a különféle tényezőknek az önkormányzati tisztviselők magatartására gyakorolt hatására vonatkozó korábbi kutatásokat követve egy 91 változóval rendelkező adatmodellt határoztunk meg (a mellékletben szereplő 5. táblázat), 3 kontrollváltozóval, 15 fiskális feltételt jelző változóval, 10 politikai versenyt jelző változóval, 4 önkormányzati méretet meghatározó változóval, 34 önkormányzati vagyont meghatározó változóval, 18 társadalmi tőkét jelző változóval, valamint 7 környezeti tőkét jelző változóval. Átvettük az előző kutatások alapvető változóit, és kiegészítettük őket a rendelkezésre álló forrásokból származó további változókkal. A főbb változók a következők voltak:

- beruházások, adósság, választási részvétel, a polgármester neme, a népesség mérete, munkanélküliség (Esteves de Araujo és Tejedo-Romero, 2016);

- önkormányzati költségvetési egyenleg, önkormányzati közkiadások, önkormányzati államadósság, politikai pártok tényleges száma, lakosok száma, munkanélküliségi ráta (Caamaño-Alegre, Lago-Peñas, ReyesSantias, és Santiago-Boubeta, 2013);

2. táblázat

AZ ADATMODELL SZERKEZETE

\begin{tabular}{|c|c|c|c|}
\hline Adatmodell & $\begin{array}{c}\text { Tényezók } \\
\text { (Muñoz és Bolívar, 2015) }\end{array}$ & $\begin{array}{l}\text { Nézốpontok } \\
\text { (Ma és Wu, 2011) }\end{array}$ & $\begin{array}{l}\text { Változók csoportjai } \\
\text { (Sol, 2013) }\end{array}$ \\
\hline Intézményi & Intézményi & & \\
\hline \multirow[t]{2}{*}{ Pénzügyi feltétel } & Pénzügyi feltétel & Fiskális teljesítmény & Fiskális változók \\
\hline & Kormányzaton belüli átadások & & \multirow[t]{2}{*}{ Intézményi és politikai változók } \\
\hline Politikai verseny & Politikai verseny & Stratégiai vezetés & \\
\hline Környezeti & Környezeti & & \\
\hline Önkormányzat mérete & Önkormányzat mérete & & \\
\hline \multirow[t]{2}{*}{ Önkormányzati vagyon } & Fejlettség & Külső igény & \multirow[t]{2}{*}{ Gazdasági környezet } \\
\hline & Bevételi szintek & \multirow[t]{3}{*}{ Erőforrások és kapacitás } & \\
\hline Társadalmi tőke & & & Szociodemográfiai \\
\hline Környezeti tőke & & & \\
\hline
\end{tabular}

Forrás: saját szerkesztés 
- átutalások/teljes bevétel, folyó átutalások/ teljes bevétel, tőkeátutalások/teljes bevétel, költségvetési hiány, tartózkodó választók, népesség, 65 év feletti népesség százalékos aránya (Esteller-Moré és Otero, 2012);

- adósság, költségvetési egyensúlyhiány, költségvetési többlet, részvételi arány, nemek megoszlása, népesség, gazdasági tevékenység, munkanélküliség, turizmus, idősek (Sol, 2013);

- az egy före jutó önkormányzati adósság, az egy före jutó önkormányzati hiány, az egy före jutó adóbevétel, az egy főre jutó regionális és központi átutalások, az önkormányzat politikai ereje, a női tagok aránya a városi tanácsban, a polgármester neme, a község népessége, az egy före jutó jövedelem, az egy före jutó jövedelem, az önkormányzattól függő jogalanyok száma, részvételi arány a legutóbbi önkormányzati választásokon (Guillamón, Bastida és Benito, 2011).

Ezen a ponton jelentős kihívást jelentett a szlovén önkormányzatok homogenitásának hiánya, amely egy megfelelő kutatási megközelítés kialakítását tette szükségessé. Amint az látható, figyelembe vettük azt a tényt, hogy a szlovén önkormányzatok között 11 városi önkormányzat található, amelyek nagyságban és fejlettségben szignifikánsan eltérnek a többitől. Ezért a leírt módszertant a szlovén önkormányzatoknak a városi önkormányzatokat nem tartalmazó halmazán alkalmaztuk, míg a városi önkormányzatok halmazán egy rövid, kvalitatív elemzést végeztünk, hogy bepillantást nyerhessünk a problémákba.

$\mathrm{Az}$ elméleteket (ügynök-, institucionalista és legitimitáselmélet) követve, figyelmünket a különböző magatartást tanúsító helyi közösségek csoportjai közötti különbségekre fordítottuk. Ennek megfelelően az önkormányzatokat két csoportra osztottuk: a szabályozásnak való megfelelésük és az átláthatóság valameny- nyi megfigyelt aspektusának teljesítése alapján. Azt feltételeztük, hogy a csoportok közötti különbségek felderítésével észlelhetők lesznek bizonyos (nem kívánatos és kívánatos) magatartástípusok okai.

A csoportok közötti különbségek vizsgálatához $t$-próbát alkalmaztunk független mintákon. A vizsgált adathalmaz nagy mérete (201 önkormányzat) miatt feltételezhettük a $t$-próba alkalmazásának megfelelő voltát. A t-próba eredményeinek (az átlagok közötti különbség) a nem paraméteres Mann-Whitney-próba (u-próba) eredményeivel (rangsorok összege) összevetésben való értelmezése még informatívabb volt. A névleges indikátorváltozók - úgy mint a polgármester neme - esetében $z$-próbát alkalmaztunk az arányok összehasonlítására. Statisztikailag szignifikáns különbségeket határoztunk meg a csoportok között, $\alpha=0,1$ szignifikanciaszint mellett.

\section{KUTATÁSI EREDMÉNYEK}

A költségvetési átláthatóság értékelése azt mutatta, hogy az átlagmutató viszonylag alacsony, mivel 3,4-es átlagértéket ért el. Ez részben a helyi költségvetések zárszámadásának elfogadásában előforduló késedelmeknek, valamint annak a ténynek tudható be, hogy sok önkormányzat a költségvetés évközi realizálásáról hírek formájában számol be, amelyeket a polgármester közöl a városi tanáccsal, az ilyen tartalmú dokumentumok azonban nem érhetők el az interneten. Az önkormányzatok a legalacsonyabb mutatót az „állampolgároknak szóló költségvetés" tekintetében produkálták, mivel Szlovénia még nem fogadta el az OECD javaslatait. Ez „egy költségvetés a nagyközönség számára”, amelynek célja a költségvetés egyszerüsített magyarázatának előmozdítása. Az egyes önkormányzatok eredményei az 1. ábrán láthatók. Érdekes megjegyezni, hogy egyetlen önkormányzat sem ért el 0 -ás mu- 


\section{ONLINE HELYI KÖLTSÉGVETÉSI ÁTLÁTHATÓSÁGI (OLBT) MUTATÓ}

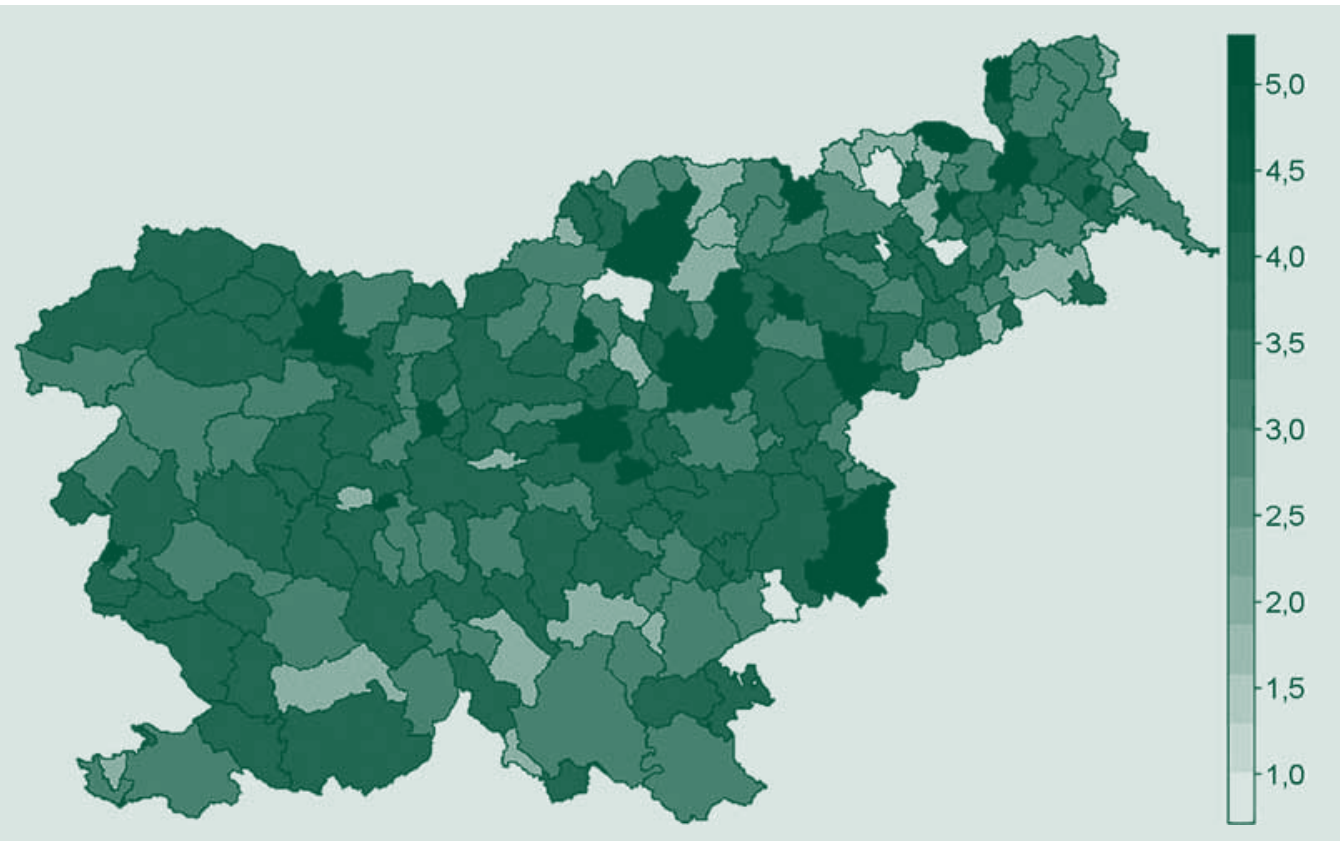

Forrás: saját szerkesztés

tatót, ami azt jelenti, hogy az önkormányzatok legalább egy költségvetéssel kapcsolatos dokumentumot közzétesznek a weboldalukon.

Amint azt az előző fejezetben említettük, a kutatás második lépése az önkormányzatoknak a költségvetési átláthatóság biztosítása terén eltérő magatartását befolyásoló tényezők elemzése volt. Az alapsokaságot a nem városi szlovén önkormányzatok halmaza adta (201 a 212-ből). Kétféle magatartást elemeztünk, öszszehasonlítva az önkormányzatok csoportjait az előírások be (nem) tartása és az átláthatóság összes aspektusának teljesítése tekintetében.

A korábbi elemzés eredményei azt mutatták, hogy 41 önkormányzat nem felel meg a költségvetési átláthatóságra vonatkozó szabályozásnak, és 160 önkormányzat teszi közzé a költségvetési dokumentumokat a szabályozásnak megfelelően. A megállapított kritéri- um alapján a teljes változóhalmazból 18 olyan változót választottunk ki, amelyek az önkormányzatok két csoportja közötti különbséget mutatják, összhangban azzal a feltételezéssel, miszerint a $t$-próba szignifikanciaszintje $\mathrm{p} \leq 0,1$ (lásd 3.táblázat). Szinte mindegyikük környezeti tényező volt, melyek három kategóriát alkotnak:

- az önkormányzat mérete (5 változó),

- társadalmi tőke (4 változó) és

• önkormányzati vagyon (7 változó).

A különbségek statisztikai jelentőségének bizonyos szintjét kifejező két fennmaradó változó politikai jellegű volt, de mindkettő a község népességétől függött (választott tisztviselők száma, jelöltek száma).

A bizonyítékok alapján arra a következtetésre jutottunk, hogy a szociodemográfiai és a gazdasági összefüggéseket lefedő környezeti ténye- 
3. táblázat

\section{A VÁLTOZÓK SZÁMTANI ÁTLAGAINAK KÜLÖNBSÉGEI AZ ÖNKORMÁNYZATOK EGYES CSOPORTJAI ESETÉBEN - JOGSZABÁLYI MEGFELELŐ́SÉG (NEM/IGEN)}

\begin{tabular}{|c|c|c|c|c|}
\hline Változí & p-érték & Kđ̈lönhség & & Besorolás \\
\hline $\begin{array}{l}\text { Magas képzettséget igénylő szakmával rendelkező } \\
\text { alkalmazottak százalékos aránya }\end{array}$ & 0,017 & $-0,02$ & Környezeti & Társadalmi tőke \\
\hline Életkor-függőségi mutató & 0,035 & $-1,62$ & Környezeti & Társadalmi tőke \\
\hline Oktatási mutató & 0,062 & $-4,01$ & Környezeti & Társadalmi tőke \\
\hline Magasan képzett emberek százalékos aránya & 0,069 & $-0,78$ & Környezeti & Társadalmi tőke \\
\hline $\begin{array}{l}\text { Szociális támogatásban részesülők (1.000 } \\
\text { lakosonként) }\end{array}$ & 0,025 & 0,54 & Környezeti & Önkormányzati vagyon \\
\hline Korai elhalálozás & 0,043 & 1,05 & Környezeti & Önkormányzati vagyon \\
\hline Búncselekménnyel vádoltak százalékos aránya & 0,054 & 0,00 & Környezeti & Önkormányzati vagyon \\
\hline Összegyüjtött hulladék kg/fő-ben kifejezve & 0,070 & $-25,18$ & Környezeti & Önkormányzati vagyon \\
\hline $\begin{array}{l}10 \text { m²-nél kisebb élettérrel rendelkező lakosok } \\
\text { százalékos aránya }\end{array}$ & 0,077 & 2,09 & Környezeti & Önkormányzati vagyon \\
\hline Nem megfelelő otthonok százalékos aránya & 0,084 & 6,04 & Környezeti & Önkormányzati vagyon \\
\hline Az 1000 lakosra jutó vállalatok száma & 0,099 & $-4,42$ & Környezeti & Önkormányzati vagyon \\
\hline Kiadások & 0,004 & $-2762141,00$ & Intézményi & Pénzügyi feltétel \\
\hline Bevételek & 0,005 & $-2725336,00$ & Intézményi & Pénzügyi feltétel \\
\hline Alkalmazásban & 0,018 & $-763,85$ & Környezeti & Önkormányzati vagyon \\
\hline Népesség & 0,019 & $-1913,23$ & Környezeti & Önkormányzat mérete \\
\hline Terület & 0,082 & $-26,36$ & Környezeti & Önkormányzat mérete \\
\hline Megválasztottak száma & 0,055 & $-1,95$ & Intézményi & Politikai verseny \\
\hline Az önkormányzati képviselőtestületi jelöltek száma & 0,107 & $-20,78$ & Intézményi & Politikai verseny \\
\hline
\end{tabular}

Forrás: saját szerkesztés

zők az elöírások betartásának mozgatórugói. Minden különbség az önkormányzatok azon csoportjának kedvez, amelyek a legkevésbé felelnek meg a szabályozásnak. Így képet nyerhetünk a szabályozás előírásainak nem megfelelő önkormányzatok jellemzőiről. Azok az önkormányzatok, amelyek nem biztosítják a költ- ségvetési átláthatóságot a szabályozással összhangban, kisebb méretűek. Más kutatások is megállapították az önkormányzatok méretének és a kiadásaik volumenének hasonló hatását (Caamano-Alegre et al. 2011; Serrano-Cinca et al. 2008; Styles és Tennyson 2007; Hemeed, 2005). Továbbá ezekben a községekben rosz- 
szabb a munkavállalók és a lakosság oktatási struktúrája. Más kutatások is megállapították a lakosság oktatási struktúrájának hasonló hatását (Perez et al., 2008; Gandia és Archidona, 2007; Serrano-Cinca et al., 2008). Végezetül az önkormányzat kevésbé vagyonos voltát

- az 1000 lakosra jutó szociális támogatásban részesülők száma,

- a korai halálozás $(\mathrm{p} \leq 0,05$ statisztikai szignifikanciaszintnél),

- a büncselekménnyel vádoltak százalékos aránya,

- az összegyüjtött hulladék mennyisége,

- a $10 \mathrm{~m}^{2}$-nél kisebb élettérrel rendelkező lakosok százalékos aránya,

- a nem megfelelő otthonok százalékos aránya, továbbá

- az 1000 lakosra jutó vállalatok száma ( $\mathrm{p} \leq 0,11$ statisztikai szignifikanciaszintnél) fejezi ki.

A fejlődésben való elmaradottság átláthatóságra gyakorolt hasonló hatását közvetett módon a Bastida és Benito (2007); Laswad et al. (2005); valamint Piotrowski és Van Ryzin (2007) által végzett kutatások is kimutatták.

Emellett egy rövid korrelációs elemzés azt mutatta, hogy az önkormányzatok (népesség) mérete a legtöbb említett változóval korrelál (magas képzettséget igénylő szakmával rendelkező alkalmazottak százalékos aránya, korai halálozás, a bűncselekménnyel vádoltak százalékos aránya, oktatási mutató, magasan képzett emberek százalékos aránya, az egy före jutó hulladék mennyisége, a $10 \mathrm{~m}^{2}$-nél kisebb élettérrel rendelkező lakosok százalékos aránya, valamint az 1000 lakosra jutó vállalatok száma). Ezen túlmenően, figyelembe véve a népességgel nem korreláló három változót (az 1000 lakosra jutó szociális támogatásban részesülők száma, életkorfüggőség és a nem megfelelő otthonnal rendelkezők százalékos aránya), a következő megállapításra jutottunk. Az önkormányzatok azon csoportja, amely nem volt képes a költségvetési átlátha- tóságnak a szabályozás által megkövetelt szintjét biztosítani, kisebb önkormányzatokból áll, amelyeknek alacsonyabb a társadalmi tőkéje és a gazdasági ereje, valamint kedvezőtlenebb a szociogazdasági helyzete.

A második összehasonlítás azokkal az önkormányzatokkal foglalkozott, amelyek biztosítják az előírt költségvetési dokumentumok közzétételét - optimális magatartásmodellel rendelkező önkormányzatok -, amelyek közzéteszik az összes vizsgált dokumentumot, és azokkal az önkormányzatokkal, amelyek nem teszik közzé egy vagy mindkét további dokumentumot (1. táblázat 3. pontja - A költségvetés végrehajtásáról szóló évközi beszámoló vagy 5. pontja - Állampolgároknak szóló költségvetés). Ugyanezen küszöbérték $\leq 0,1$ (lásd 4. táblázat) használatával kinyertünk négy intézményi és nyolc környezeti tényezőt. Két intézményi tényező tartozott a politikai verseny kategóriájába, míg két másik a pénzügyi feltétel kategóriájába. A környezeti tényezők a kategóriák némileg színesebb halmazát ölelik fel, amelyek közül négy változó jelzi az önkormányzati vagyont, két változó az önkormányzat méretét, és egyetlen változó tartozik a másik két kategóriához (környezeti tőke és társadalmi tőke). Az eredmények a többi tanulmányéhoz hasonló változókra mutatnak. Mivel a teljes költségvetési átláthatóságot biztosító helyi önkormányzatoknak férfi polgármestere volt, a polgármestert nem cserélték le a legutóbbi választásokon, az összkiadásban nagyobb arányt képviseltek a munkabérek és az anyagköltségek, és alacsonyabbak voltak az egy fơre jutó kiadások (például Esteves de Araujo és Tejedo-Romero, 2016; Alesina, Troiano és Cassidy, 2015; Lee, Moretti és Butler, 2004; Ferreira és Gyourko, 2009 és 2014). Az önkormányzati vagyont jelző tényezőknél a környezeti tényezőknek alacsonyabb volt az értéke (alkalmazottankénti bruttó hozzáadott érték, átlag nettó munkabér, helyi gazdaságba történő beruházás), a kis lakóterüle- 


\begin{tabular}{|c|c|c|c|c|}
\hline \multicolumn{5}{|c|}{$\begin{array}{l}\text { A VÁLTOZÓK SZÁMTANI ÁTLAGAINAK KÜLÖNBSÉGEI AZ ÖNKORMÁNYZATOK EGYES } \\
\text { CSOPORTJAI ESETÉBEN - VALAMENNYI KÖZZÉTETT DOKUMENTUM (NEM/IGEN) }\end{array}$} \\
\hline Változó & p-érték & Különhség & & Besorolás \\
\hline Munkanélküliség változása & 0,108 & 0,846 & Környezeti & Önkormányzati vagyon \\
\hline $\begin{array}{l}\text { Natura } 2000 \text { környezetvédelmi területek százalékos } \\
\text { aránya }\end{array}$ & 0,005 & 15,740 & Környezeti & Környezeti tőke \\
\hline Korösszetétel változása & 0,017 & $-0,028$ & Környezeti & Társadalmi tőke \\
\hline Munkavállalónkénti bruttó hozzáadott érték & 0,002 & 4009,000 & Környezeti & Önkormányzati vagyon \\
\hline Átlagos nettó munkabér & 0,037 & 36,650 & Környezeti & Önkormányzati vagyon \\
\hline Helyi gazdaságba történő beruházás & 0,063 & 455,070 & Környezeti & Önkormányzati vagyon \\
\hline Átlagos bruttó munkabér & 0,069 & 57,150 & Környezeti & Önkormányzati vagyon \\
\hline $\begin{array}{l}10 \text { m²-nél kisebb élettérrel rendelkező lakosok } \\
\text { százalékos aránya }\end{array}$ & 0,069 & 1,760 & Környezeti & Önkormányzati vagyon \\
\hline Sürüség & 0,008 & $-49,920$ & Környezeti & Önkormányzat mérete \\
\hline Terület & 0,046 & 41,320 & Környezeti & Önkormányzat mérete \\
\hline $\begin{array}{l}\text { A munkabérek és anyagköltségek részesedése az } \\
\text { összes kiadásból }\end{array}$ & 0,055 & $-1,590$ & Intézményi & Pénzügyi feltétel \\
\hline nettó folyó kiadások/fő & 0,109 & 36,180 & Intézményi & Pénzügyi feltétel \\
\hline Polgármester neme & 0,000 & 0,094 & Intézményi & Politikai verseny \\
\hline Polgármester leváltása & 0,032 & 0,190 & Intézményi & Politikai verseny \\
\hline
\end{tabular}

Forrás: saját szerkesztés

ten élők százalékos arányának kivételével. Az e csoportba tartozó községek kisebb területüek és sűrűbben lakottak. Ezen túlmenően kisebb arányban találhatók itt Natura 2000 területek, és rosszabb a korstruktúra változásának irányvonala. Azt vártuk, hogy a csoportok közötti különbségek elemzése az elméleti kiindulópontokkal összhangban lévő eredményeket produkál, csakúgy mint az előző összehasonlítás esetében. Azonban, éppen ellenkezőleg, azt fedeztük fel, hogy a teljes költségvetési átláthatóságot biztosító önkormányzatok nem tapasztalták az elméletileg várt ösztönzőket.
A megállapított tények a 11 városi önkormányzatra is vonatkoznak, amelyek közül 2 nem teljesíti az átláthatóságra vonatkozó jogi követelményeket, és 9 felel meg a jogszabályoknak, vagyis tesz közzé egy további, évközi beszámolót. Ezek közül 2 biztosítja a teljes körü költségvetési átláthatósági tényezők teljes körét. Mindkét tárgyalt jelenség hasonló módon fejeződik ki a városi önkormányzatok esetében, mint a nem városi önkormányzatok halmazában. Mindkét olyan önkormányzat, amely nem biztosítja az elöírt dokumentumok közzétételét, Szlovénia észak-keleti részén található, és 
mindkettőt nehéz gazdasági és társadalmi helyzet jellemzi. A dokumentumok teljes halmazát közzétevő önkormányzatok kisebb méretűek és gazdaságilag gyengébbek, csakúgy mint a nem városi önkormányzatok esetében.

\section{KÖVETKEZTETÉS}

Amint azt már említettük, elemeztük az önkormányzati csoportok két párja közötti különbségeket a fiskális átláthatóság intézményi (pénzügyi helyzet, kormányközi támogatások és politikai verseny), valamint környezeti tényezői (önkormányzat mérete, jövedelmi szintje és vagyona) tekintetében. Az ügynökés legitimitáselmélettel összhangban azt vártuk, hogy az egyes kategóriákban legalább néhány változó esetében különbségeket fogunk találni. Több más kutatóhoz hasonlóan azonban nem tudtuk igazolni az összes elméleti várakozást. Ezen kívül a teljes költségvetési átláthatóságot biztosító önkormányzatoknál az eredmények épp ellentétesek voltak a várakozásokkal.

A szabályozásnak megfelelő, illetve meg nem felelö önkormányzatok összehasonlításából származó bizonyíték arra mutatott rá, hogy az intézményi tényezőknek nincs befolyása a költségvetés átláthatóságára. Így arra a következtetésre jutottunk, hogy ebben az esetben az ügynökelmélet nem alkalmazható. Mindezek ellenére a legitimitáselméletet alkalmazni tudtuk, azzal érvelve, hogy a nagyobb és fejlettebb önkormányzatok hivatalnokai hajlamosak teljesíteni az érdekeltek elvárásait. Továbbá, az előírásokat nem teljesítő önkormányzatok valószínűleg túl kevés erőforrással rendelkeznek, vagy más kihívások miatt kevésbé koncentrálnak a fiskális információk közzétételére.
A teljes költségvetési átláthatóságot biztosító önkormányzatok és az elöírásokat kielégíto” más önkormányzatok összehasonlítása éppen ellentétes eredményeket hozott (lásd 4. táblázat). Mind az intézményi, mind a környezeti változók (kivéve a kis lakóterülettel rendelkező lakosok százalékos arányát) a várttal ellentétes értékeket eredményeztek. A szakirodalmi kutatásunk során nem találtunk ehhez hasonló bizonyítékot, a jelenség azonban valamilyen módon magyarázható az ügynök- és a legitimitáselmélettel. Nevezetesen feltettük azt a kérdést, hogy „milyen tényezők késztették az önkormányzatot a költségvetési információk önkéntes nyilvánosságra hozatalára”. Ez azt jelentette, hogy a kevésbé vagyonos önkormányzatoknál dolgozó ügynökök extra erőfeszítéseket tettek annak érdekében, hogy az információt jobban láthatóvá tegyék a megbízó számára. Az átláthatóság növeli a bizalom mértékét és a politikai szereplőkbe vetett közbizalmat (Laswad et al., 2005). Emellett a kormányzati döntéshozatal és a tevékenységek fokozott átláthatósága fokozza a demokráciának és az állampolgárok bevonásának valószínűségét (Esteves de Araujo és TejedoRomero, 2016), amely elősegítheti az önkormányzatok fejlődését. Ezen túlmenően, mivel az információk közzététele az egyik módja annak, hogy cselekedeteiket legitimizálják az érdekeltek szemében (Archel et al., 2009), a kevésbé sikeres önkormányzatok hivatalnokai hajlamosak elnyerni, visszanyerni az állampolgárok bizalmát és megváltoztatni a szervezetekről alkotott elképzelését.

Mivel ezek az önkormányzatok átfogó tájékoztatást nyújtanak az állampolgárok számára, ezt a jelenséget az „állampolgárokra való összpontosításnak" is nevezhetjük. Ez egy további szempont, amelyet a jelen esetben nem vizsgálunk. 
MELlÉKLET

5. táblázat

\section{AZ ELEMZÉSHEZ FELHASZNÁLT 91 VÁLTOZÓ, AZOK MÉRTÉKEGYSÉGÉVEL ÉS A FORRÁSSAL EGYÜTT, AMELYBỐL SZÁRMAZNAK}

\begin{tabular}{|c|c|c|c|}
\hline Változó & Mértékegység & Osztály & Forrás \\
\hline Régi önkormányzat & $\begin{array}{l}\text { Indikátorváltozó (dummy változó): } 1 \text { - 1991- } \\
\text { ben hozták létre, } 0 \text { - } 1991 \text { után hozták létre }\end{array}$ & CV & SORS \\
\hline Kohéziós politikában érdekelt régió & $\begin{array}{l}\text { Kohéziós politikában érdekelt régió: } 1 \text { - } \\
\text { Kelet-Szlovénia, } 2 \text { - Nyugat-Szlovénia }\end{array}$ & CV & SORS \\
\hline Statisztikai régió & Szlovénia 12 statisztikai régiójának egyike & CV & SORS \\
\hline 2015. évi bevételek & EUR & FC & MF \\
\hline 2015. évi kiadások & EUR & FC & MF \\
\hline 2015. évi hiány/többlet & EUR & FC & MF \\
\hline $\begin{array}{l}\text { A munkabérek és anyagköltségek részesedése az } \\
\text { összes kiadásból }\end{array}$ & Százalék & FC & MF \\
\hline $\begin{array}{l}\text { A kormányzati támogatás részesedése a városok } \\
\text { költségvetésében }\end{array}$ & Százalék & $\mathrm{FC}$ & MF \\
\hline $\begin{array}{l}\text { Költségvetési és hatékonysági mutató - a } \\
\text { változókból származó összesített mutató magyarázó } \\
\text { jegyzettel }\end{array}$ & Mutató & FC & GS \\
\hline Megszerzett uniós források & EUR & $\mathrm{FC}$ & GS \\
\hline Nem átruházható és tartós bevételek növekedése & Százalék & FC & GS \\
\hline Eladósodottság & EUR & FC & GS \\
\hline Adósság növekedése & EUR & $\mathrm{FC}$ & GS \\
\hline Nettó folyó kiadások (tényl.) & EUR & $\mathrm{FC}$ & GS \\
\hline A közigazgatási kiadások növekedése (tényl.) & százalék & $\mathrm{FC}$ & GS \\
\hline Beruházások (tényl.) & EUR & FC & GS \\
\hline Az önkormányzatok pénzügyi függetlensége & Mutató & FC & GS \\
\hline $\begin{array}{l}\text { Öneltartási mutató - a változókból származó } \\
\text { összesített mutató magyarázó jegyzettel }\end{array}$ & Mutató & FC & GS \\
\hline $\begin{array}{l}\text { Környezeti mutató - a változókból származó } \\
\text { összesített mutató magyarázó jegyzettel }\end{array}$ & Mutató & EC & GS \\
\hline Polgármester leváltása a legutóbbi választások során & $\begin{array}{l}\text { Indikátorváltozó (dummy változó): } 1 \text { - új } \\
\text { polgármester, } 0 \text { - régi polgármester }\end{array}$ & $\mathrm{PC}$ & SEC \\
\hline Az önkormányzati képviselőtestületi jelöltek száma & Szám & PC & SEC \\
\hline Megválasztottak száma & Szám & PC & SEC \\
\hline
\end{tabular}




\begin{tabular}{|c|c|c|c|}
\hline Változó & Mértékegység & Osztály & Forrás \\
\hline Megválasztott jelöltek aránya & Százalék & PC & SEC \\
\hline $\begin{array}{l}\text { A helyi törvényhozó testületben magukat képviseltető } \\
\text { politikai pártok száma }\end{array}$ & Szám & PC & SEC \\
\hline Polgármester neme & Bináris változó: 1 - férfi, 2 - nő & PC & SEC \\
\hline A polgármester politikai pártja & $\begin{array}{l}\text { Bináris változó: } 0 \text { - helyi párt, } 1 \text { - Nemzeti } \\
\text { párt }\end{array}$ & PC & SEC \\
\hline Mandátum & Szám & PC & SEC \\
\hline A megválasztott polgármesterre szavazók \%-a & Százalék & PC & SEC \\
\hline Polgármester fizetése & EUR & PC & MF \\
\hline Terület & $\mathrm{Km}^{2}$ & MS & SORS \\
\hline Népesség & Szám & MS & SORS \\
\hline Súrűség & Fő/km² & MS & SORS \\
\hline Települések száma & Szám & MS & SORS \\
\hline Átlagjövedelem/fő & EUR & MW & SORS \\
\hline Alkalmazásban & Szám & MW & SORS \\
\hline Munkanélküliségi ráta & Százalék & MW & SORS \\
\hline Átlagos bruttó munkabér & EUR & MW & SORS \\
\hline Önkormányzatok közötti nettó migráció & Mutató & MW & SORS \\
\hline Nettó migráció & 1000 lakosra vetítve & MW & GS \\
\hline $\begin{array}{l}\text { Gazdasági mutató - a változókból származó } \\
\text { összesített mutató magyarázó jegyzettel }\end{array}$ & Mutató & MW & GS \\
\hline Kisüzemi gazdaság előmozdítása & EUR & MW & GS \\
\hline Hozzáadott érték & EUR/lakos & MW & GS \\
\hline Gazdaságba történő bruttó beruházás & EUR/lakos & MW & GS \\
\hline Vállalatok száma & 1000 lakosra vetített szám & MW & GS \\
\hline Vállalatok számának változása & 1000 lakosra vetített szám & MW & GS \\
\hline Új üzleti vállalkozások & 1000 lakosra vetített szám & MW & GS \\
\hline Bevételnövekedés & Százalék & MW & GS \\
\hline $\begin{array}{l}\text { Munkaerőpiaci mutató - a változókból származó } \\
\text { összesített mutató magyarázó jegyzettel }\end{array}$ & Mutató & MW & GS \\
\hline Aktív foglalkoztatáspolitikára szánt források (Im) & EUR/lakos & MW & GS \\
\hline Foglalkoztatottak aránya & Százalék & MW & GS \\
\hline Munkahelyek száma a községben & 1000 lakosra vetítve & MW & GS \\
\hline $\begin{array}{l}\text { Foglalkoztatási struktúra - felsófokú iskolai } \\
\text { végzettséget igénylő munkahelyek százalékos aránya }\end{array}$ & Százalék & MW & GS \\
\hline
\end{tabular}




\begin{tabular}{|c|c|c|c|}
\hline Változó & Mértékegység & Osztály & Forrás \\
\hline Munkahelyek számának változása & Százalék & MW & GS \\
\hline A munkanélküliségben bekövetkezett mozgás & Százalék & MW & GS \\
\hline $\begin{array}{l}\text { Életszínvonal mutató - a változókból származó } \\
\text { összesített mutató magyarázó jegyzettel }\end{array}$ & Mutató & MW & GS \\
\hline Kultúrára fordított költségvetési kiadások & EUR/lakos & MW & GS \\
\hline Sportra fordított költségvetési kiadások & EUR/lakos & MW & GS \\
\hline Nettó munkabérek & EUR & MW & GS \\
\hline Átlagos bruttó bevételek & EUR & MW & GS \\
\hline $\begin{array}{l}\text { A } 10 \text { m²-nél kisebb lakóterületen élő népesség } \\
\text { aránya }\end{array}$ & 1000 lakosra vetítve & MW & GS \\
\hline Szociális támogatásban részesülők & 1000 lakosra vetítve & MW & GS \\
\hline $\begin{array}{l}\text { Olyan lakott otthonok aránya, amelyek nincsenek } \\
\text { ellátva az alapvetőnek számító közmúvek } \\
\text { mindegyikével }\end{array}$ & 1000 lakosra vetítve & MW & GS \\
\hline Korai elhalálozás & 1000 lakosra vetítve & MW & GS \\
\hline Az átlagos bruttó kereset változása & Százalék & MW & GS \\
\hline $\begin{array}{l}\text { A szennyvízhálózatra újonnan történt } \\
\text { rácsatlakozások }\end{array}$ & 1000 lakosra vetítve & MW & GS \\
\hline $\begin{array}{l}\text { Társadalmi kohézió és politikai kultúra mutató - a } \\
\text { változókból származó összesített mutató magyarázó } \\
\text { jegyzettel }\end{array}$ & Mutató & MW & GS \\
\hline $\begin{array}{l}\text { Nemzetközi együttmúködésre fordított költségvetési } \\
\text { kiadások }\end{array}$ & EUR/lakos & MW & GS \\
\hline Magasan képzett emberek százalékos aránya & Százalék & SC & SORS \\
\hline 65 évnél idősebbek százalékos aránya & Százalék & SC & SORS \\
\hline Büncselekménnyel vádoltak százalékos aránya & Százalék & SC & SORS \\
\hline Részvételi arány a legutóbbi választásokkor & Százalék & SC & SEC \\
\hline Demográfiai mutató & Mutató & SC & GS \\
\hline $\begin{array}{l}\text { Elöregedési mutató - a változókból származó } \\
\text { összesített mutató magyarázó jegyzettel }\end{array}$ & Mutató & SC & GS \\
\hline Életkor-függőségi együttható & Arány & SC & GS \\
\hline Lakosok számának változása & Százalék & SC & GS \\
\hline A korszerkezet változása & Százalék & SC & GS \\
\hline $\begin{array}{l}\text { Oktatási mutató - a változókból származó összesített } \\
\text { mutató magyarázó jegyzettel }\end{array}$ & Mutató & SC & GS \\
\hline Önkormányzati támogatások & EUR-ban, 1000 lakosra vetítve & SC & GS \\
\hline
\end{tabular}




\begin{tabular}{|c|c|c|c|}
\hline Változó & Mértékegység & Osztály & Forrás \\
\hline $\begin{array}{l}\text { Oktatási struktúra - magasan képzett emberek } \\
\text { százalékos aránya }\end{array}$ & Százalék & SC & GS \\
\hline Diplomások aránya & 1000 lakosra vetítve & SC & GS \\
\hline Új doktori vagy mesterfokozatú diplomások száma & 1000 lakosra vetítve & SC & GS \\
\hline Az oktatási szerkezet változása & Százalékpont & SC & GS \\
\hline Részvétel & Százalék & SC & GS \\
\hline Elitélt bünözők & 1000 lakosra vetítve & SC & GS \\
\hline A tartósan munkanélküli lakosság aránya & Százalék & SC & GS \\
\hline Környezeti kiadások & EUR/lakos & EC & GS \\
\hline $\begin{array}{l}\text { A hatékony energiafelhasználás népszerüsítésére } \\
\text { fordított kiadások }\end{array}$ & EUR/lakos & EC & GS \\
\hline Selejt & $\mathrm{kg} / \mathrm{lakos}$ & EC & GS \\
\hline Natura 2000 & Százalék & EC & GS \\
\hline Hulladékmennyiség növekedése & Százalék & $\mathrm{EC}$ & GS \\
\hline Végső mutató & Mutató & EC & GS \\
\hline
\end{tabular}

Megjegyzések: Osztály: CV: kontrollváltozó, FC: gazdasági feltétel, PC: politikai verseny, MS: önkormányzat mérete, MW: önkormányzati vagyon, SC: társadalmi tőke, EC: környezeti tôke.

Források: SORS: a Szlovén Köztársaság Statisztikai Hivatala, MF: Pénzügyminisztérium, SEC: Állami Választási Bizottság, GS: Golden Stone

\section{JEGYZETEK}

1 A jelen munkát a Horvát Tudományos Alap támogatta az IP-2014-09-3008 számú projekt keretében, valamint a Szlovén Kutatási Ügynökség az ID P5-0093 számú projekt keretében.

2 Azt állapították meg, hogy az adósság pozitív hatással volt az első részleges átláthatósági mutatójukra.

\section{IRODALOM}

Albalate Del Sol (2013). The institutional, economic and social determinants of local government transparency. [A helyi önkormányzatok átláthatóságát meghatározó intézményi, gazdasági és társadalmi tényezők.] Journal of Economic Policy Reform, 16 (1), pp. 90-107, https://doi.org/10.1080/17487870.2012.759422
Alcaide-Muñoz, L., Rodríguez-Bolívar, M. P. (2015). Determing Factors of Transparency and Accountability in Local Governments: A MetaAnalytic Study. [Az átláthatóság és elszámoltathatóság meghatározó tényezői a helyi önkormányzatoknál: egy metaanalitikai tanulmány.] Lex Localis, 13(2), pp. 129160, https://doi.org/10.4335/13.2.129-160(2015) 
Alesina, A., Perotti, R. (1996). Fiscal Discipline and the Budget Process. [Fiskális fegyelem és a költségvetési folyamat.] The American Economic Review, 86(2), pp. 401-407

Alesina, A., Hausmannb, R., Hommesc, R., Steinb, E. (1999). Budget institutions and fiscal performance in Latin America. [Költségvetési intézmények és fiskális teljesítmény Latin-Amerikában.] Journal of Development Economies, 59(2), pp. 253-273,

https://doi.org/10.1016/S0304-3878(99)00012-7

Alesina, A. F., Troiano, U., Cassidy, T. (2015). Old and Young Politicians [Idős és fiatal politikusok] (w20977 sz.). Nemzeti Gazdaságkutató Iroda (National Bureau of Economic Research),

https://doi.org/10.3386/w20977

Alt, J. E., Lassen, D. D., Skilling, D. (2002). Fiscal transparency, gubernatorial popularity, and the scale of government: evidence from the states. [Fiskális átláthatóság, kormányzói népszerűség és a kormányzás mértéke: az államokból származó bizonyítékok.] A Gazdaságpolitikai Kutatási Egység (EPRU) 2001-2016 munkadokumentuma, Koppenhágai Egyetem, https://doi.org/10.1177/153244000200200302

Alt, J. E., Lassen, D. D., Rose, S. (2006). The Causes of Fiscal Transparency: Evidence from the American States. [A fiskális átláthatóság okai: az amerikai államokból származó bizonyítékok.] A Gazdaságpolitikai Kutatási Egység (EPRU) munkadokumentum sorozata, 06-02., http://www.econ.ku.dk/eprn_epru/Workings_ Papers/wp-06-02.pdf

Alt, J. E., Lowry, R. C. (2010). Transparency and Accountability: Empirical Results for Us States. [Átláthatóság és elszámoltathatóság: az USA államainak empirikus eredményei.] Journal of Theoretical Politics, 22(4), pp. 379-406, https://doi.org/10.1177/0951629810375641
Archel, P., Husillos, J., Larrinaga, C., Spence, C. (2009). Social disclosure, legitimacy theory and the role of the state. [Társadalmi információk közzététele, legitimitáselmélet és az állam szerepe.] $A c$ counting, Auditing \& Accountability Journal, 22(8), pp. 1284-1307,

https://doi.org/10.1108/09513570910999319

Barro, R. (1973). The Control of Politicians. An Economic Model. [A politikusok feletti ellenőrzés. Egy közgazdaságtani modell.] Public Choice, 14., pp. 19-42, https://doi.org/10.1007/bf01718440

Bastida, F., Benito, B. (2007). Central Government Budget Practices and Transparency: An International Comparison. [Központi kormányzati költségvetési gyakorlatok és átláthatóság: nemzetközi összehasonlítás.] Public Administration, 85(3), pp. 667-716, https://doi.org/10.1111/j.1467-9299.2007.00664.x

Beales, J., Thompson, M.W. (2010). Government transparency in Virginia: How localities compare. [Kormányzati átláthatóság Virginiában: Miben hasonlítanak a települések.] The Thomas Jefferson Institute for Public Policy (Thomas Jefferson Közpolitikai Intézet), http://www. thomasjeffersoninst. org/pdf/articles/Govt_Transparency_LocalGov. pdf

Bolívar, M. P. R., Pérez, M. del C. C., LópezHernández, A. M. (2013). Online Budget Transparency in OECD Member Countries and Administrative Culture. [Online költségvetési átláthatóság az OECD-tagországokban és a közigazgatási kultúra.] Administration \& Society, 95399713509238 , http://doi.org/10.1177/0095399713509238

Bolívar, M. P. R., Muñoz, L. A., Hernández, A. M. L. (2013). Determinants of Financial Transparency in Government. [A pénzügyi átláthatóságot meghatározó tényezők a kormányzatban.] International Public Management Journal, 16(4), pp. 557-602, https://doi.org/10.1080/10967494.2013.849169 
Boubeta, A. S., Santias, F. R., Alegre, J. C. (2010). Budget Transparency in Local Government: Empirical Analysis on a Sample of 33 Galician Municipalities. [Költségvetési átláthatóság a helyi önkormányzatokban: 33 galíciai községből álló mintán végzett empirikus elemzése.], http://www. um.es/dp-hacienda/eep2010/comunicaciones/ eep2010-65.pdf,

https://doi.org/10.1080/03003930.2012.693075

CaAmaño-Alegre, J. et al. (2011). Budget Transparency in Local Governments: An Empirical Analysis. [Költségvetési átláthatóság a helyi önkormányzatokban: egy empirikus elemzés.] Atlanta: Georgia State University - Andres Young School of Policy Studies (Georgiai Állami Egyetem - Andres Young Politikatudományi Iskola, https://doi.org/10.2139/ssrn.1768091

Caamaño-Alegre, J., Lago-Peñas, S., ReyesSantias, F., Santiago-Boubeta, A. (2013). Budget Transparency in Local Governments: An Empirical Analysis. Local Government Studies. [Költségvetési átláthatóság a helyi önkormányzatokban: egy empirikus elemzés.] Local Government Studies, 39(2), pp. 182-207,

https://doi.org/10.1080/03003930.2012.693075

Esteller-Moré, A., Otero, J. P. (2012). Fiscal transparency: (why) does your local government respond? [Fiskális átláthatóság: (miért) reagál az Önök helyi önkormányzata?] Public Management Review. 14(8),

https://doi.org/10.1080/14719037.2012.657839

Esteves de Araujo, J. F. F., Tejedo-Romero, F. (2016). Local government transparency index: determinants of municipalities' rankings. [Helyi önkormányzati átáthatósági mutató: az önkormányzatok rangsorolását meghatározó tényezők.] International Journal of Public Sector Management. 29(4), pp. 327-347,

https://doi.org/10.1108/ijpsm-11-2015-0199
Fama, E. F. (1980). Agency Problems and the Theory of the Firm. [Ügynöki problémák és a vállalat elmélete.] Journal of Political Economy, 88(2), pp. 288-307, https://doi.org/10.1086/260866

Ferejohn, J. (1986). Incumbent Performance and Electoral Control. [Hivatalnoki teljesítmény és választói ellenőrzés.] Public Choice, 50, pp. 5-25, https://doi.org/10.1007/bf00124924

Ferejohn, J. (1999). Accountability and Authority: Toward a Theory of Political Accountability. [Elszámoltathatóság és fennhatóság: a politikai elszámoltathatóság elmélete felé.] In A. Przeworski, S. C. Stokes - B. Manin (szerk.), Democracy, Accountability, and Representation. [Demokrácia, elszámoltathatóság és képviselet.] Cambridge University Press, pp. 131-153, https://doi.org/10.1017/СBO9781139175104.005

Ferreira, F., Gyourko, J. (2009). Do Political Parties Matter? Evidence from US Cities. [Számítanak a politikai pártok? Amerikai városokból származó bizonyítékok.] The Quarterly Journal of Economics, 124(1), pp. 399-422, https://doi.org/10.3386/w13535

Ferreira, F., Gyourko, J. (2014). Does gender matter for political leadership? The case of US mayors. [Számít a nem a politikai vezetésben? Amerikai polgármesterek esete.] Journal of Public Economics, 112., pp. 24-39, https://doi.org/10.1016/j.jpubeco.2014.01.006

De Fine Licht, J., Naurin, D., Esaiasson, P., Gilljam, M. (2011). Does transparency generate legitimacy? An experimental study of procedure acceptance of open and closed-door decisionmaking, working paper, The Quality of Government Institute, University of Gothenburg, Gothenburg. [Az átláthatóság legitimitást teremt? A nyitott és zárt ajtók mögött zajló döntéshozatal folyamatának elfogadottságát vizsgáló kísérleti tanulmány, munkado- 
kumentum, a Göteborgi Egyetem Kormányzási Minőségi Intézete, Göteborg.]

Fox, R. L., Schuhmann, R. A. (1999). Gender and Local Government: A Comparison of Women and Men City Managers. [Nem és önkormányzat viszonya: a férfi és női városvezetők összehasonlítása.] Public Administration Review, 59(3), pp. 231-242, https://doi.org/10.2307/3109951

Fung, A. (2013). Infotopia. Politics \& Society. [Infotópia. Politika és társadalom.] 41(2), pp. 183-212, https://doi.org/10.1177/0032329213483107

Gandia, J. L., Archidona, M. C. (2007). Determinants of web site information by Spanish city councils. [A spanyolországi városi tanácsok által közzétett webes információkat meghatározó tényezők.] Online Information Review, 32(1), pp. $36-57$

Gandía, J. L., Archidona, M. C. (2008) Determinants of web site information by Spanish city councils. [A spanyolországi városi tanácsok által közzétett webes információkat meghatározó tényezők.] Online Information Review, 32(1), pp. $35-57$,

https://doi.org/10.1108/14684520810865976

García, A. C., García-García, J. (2010). Determinants of Online Reporting of Accounting Information by Spanish Local Government Authorities. [A számviteli információk spanyol helyi önkormányzati hatóságok általi online jelentését meghatározó tényezők.] Local Government Studies, 36(5), pp. 679-695,

https://doi.org/10.1080/03003930.2010.506980

Gerunov, A. (2016). Financial Effects of Fiscal Transparency: A Critique. [A fiskális átláthatóság pénzügyi hatásai: egy kritika.] Bulgarian Economic Papers, 2016(1), p. 19, http://www.bep.bg/p/papers. html.
Giroux, G., McLelland, A. J. (2003). Governance Structures and Accounting at Large Municipalities. [Kormányzási struktúrák és számvitel a nagyobb önkormányzatoknál.] Journal of Accounting and Public Policy, 22(3), pp. 203-230, https://doi.org/10.1016/S0278-4254(03)00020-6

Guillamón, M.-D., Bastida, F., Benito, B. (2011). The Determinants of Local Government's Financial Transparency. [A helyi önkormányzatok pénzügyi átláthatóságát meghatározó tényezők.] Local Government Studies, 37(4), pp. 391-406, https://doi.org/10.1080/03003930.2011.588704

Hameed, F. (2005). Fiscal Transparency and Economic Outcomes. [Fiskális átláthatóság és gazdasági eredmények.] A Nemzetközi Valutaalap munkadokumentuma, 225., http://www.imf.org/external/ pubs/ft/wp/2005/wp05225.pdf, https://doi.org/10.5089/9781451862447.001

Heald, D. (2006). Varieties of transparency. [Az átláthatóság fajtái.] In: Hood, C. - Heald, D. (szerk.), Transparency: The Key to Better Governance? [Átláthatóság: A jobb kormányzás kulcsa?], Oxford University Press, Oxford, pp. 25-43, https://doi.org/10.5871/bacad/9780197263839.003.0002

Heers, R. (2005). E-Government as a Carrier of Context. [Az e-kormányzat mint összefüggés-hordozó.] Journal of Public Policy, 25(1), pp. 51-74, https://doi.org/10.1017/s0143814x05000206

Heyndels, B., Smolders, C. (1994). Source fiscal illusion at the local level: empirical evidence for the flemish municipalities. [A fiskális illúzió forrása helyi szinten: empirikus bizonyíték a flamand önkormányzatok esetében.] Public Choice. 80(3/4), pp. 325-338

https://doi.org/10.1007/bf01053224

Jarmuzek, M., Polgar, E. K., Matousek, R., Hölscher, J. (2009). Fiscal Transparency in Transition Economics. [Fiskális átláthatóság az át- 
meneti gazdaságtanban.] Studies and Analyses (328). http://www.case-research.eu/upload/publikacja_ plik/11096266_sa328.pdf

Jensen, M., W. Meckling (1976). Theory of the Firm: Manageral Behaviour, Agency Costs and Ownership Structure. [A vállalat elmélete: vezetői magatartás, ügynöki költségek és tulajdonosi szerkezet.] Journal of Financial Economics. 3., pp. 305-360, https://doi.org/10.1016/0304-405X(76)90026-X

Jordan, M. M., Yusuf, J.-E., Berman, M., Gilchrist, C. (2017). Popular Financial Reports as Fiscal Transparency Mechanisms: An Assessment Using the Fiscal Transparency Index for the Citizen User. [A népszerű pénzügyi beszámolók mint fiskális átláthatósági mechanizmusok: a fiskális átláthatósági mutató állampolgár felhasználók esetében történő alkalmazásával végzett felmérés.] International Journal of Public Administration, 40(8), pp. 625-636, https://doi.org/10.1080/01900692.2016.1186175

Kopits, G., Craig, J., (1998). Transparency in government operations. [A kormányzati műveletek átláthatósága.] IMF Occasional Paper, 158. Washington, DC: Nemzetközi Valutaalap, https://doi.org/10.5089/9781557756978.084

Kraemer, K., King, J. L. (2006). Information Technology and Administrative Reform: Will e-Government be different? [Informatika és közigazgatási reform: az e-kormányzat más lesz?] International Journal of Electronic Government Research, 2(1), pp. 1-20, https://doi.org/10.4018/jegr.2006010101

Кroth, V. (2012). Subnational Budget Transparency: An Analysis of Ten Pilot Studies. [Szubnacionális költségvetési átláthatóság: tíz kísérleti tanulmány elemzése.] http://internationalbudget. org/wp-content/uploads/Subnational-SynthesisPaper_final.pdf

Laswad, F., Fisher, R., Oyelere, P. (2005). Determinants of voluntary Internet financial reporting by local government authorities. [A helyi önkormányzati hatóságok önkéntes internetes pénzügyi beszámolását meghatározó tényezők.] Journal of Accounting and Public Policy, 24., pp. 101-121, https://doi.org/10.1016/j.jaccpubpol.2004.12.006

Lawson, A., Alvarez, G. (2013). International Budget Partnership : Synthesis Report on the piloting of the Subnational Open Budget Survey in Brazil, Indonesia and Tanzania. [Nemzetközi Költségvetési Partnerség: összefoglaló jelentés a Szubnacionális Nyitott Költségvetési Felmérés Brazíliában, Indonéziában és Tanzániában végzett kísérleti alkalmazásáról.] A FISCUS Public Finance Consultants (Egyesült Királyság) által a Nemzetközi Költségvetési Partnerség kapcsán benyújtott zárójelentés,http:// internationalbudget.org/wp-content/uploads/IBPSynthesis-Report-on-SN-OBS-Pilot-Surveys_ final020714.pdf

Lee, D. S., Moretti, E., Butler, M. J. (2004). Do voters affect or elect policies? Evidence from the US House. [Vajon a választók hatással vannak a szakpolitikákra vagy megválasztják azokat? Az USA Parlamentjének alsóházából származó bizonyítékok.] The Quarterly Journal of Economics, 119(4), pp. 807-859, https://doi.org/10.1162/0033553041502153

MA, L., Wu, J. (2011). What Drives Fiscal Transparency? Evidence from Provincial Governments in China [Mi ösztönzi a fiskális átláthatóságot? Kína tartományi kormányzataiból származó bizonyítékok] (az SSRN 1807767 számú tudományos kiadványa). Rochester, NY: Social Science Research Network (Társadalomtudományi Kutatási Hálózat), https://papers.ssrn.com/abstract=1807767, https://doi.org/10.2139/ssrn.1807767

De Mello, L. R. (2004). Can Fiscal Decentralization Strengthen Social Capital? [Képes a fiskális decentralizáció erősíteni a társadalmi tőkét?] Public Finance Review, 32(1), pp. 4-35, https://doi.org/10.1177/1091142103260699 
Meyer, J. W., B. Rowan. (1977). Institutionalized Organizations: Formal Structure as Myth and Ceremony. [Intézményesedett szervezetek: a formális struktúra mint mítosz és szertartás.] American Journal of Sociology, 83(2), pp. 340-363,

https://doi.org/10.1086/226550

Muñoz, L. A., Bolívar, M. P. R. (2015). Determing Factors of Transparency and Accountability in Local Governments: A MetaAnalytic Study. [Az átláthatóság és elszámoltathatóság meghatározó tényezői a helyi önkormányzatoknál: egy metaanalitikai tanulmány.] Lex Localis - Journal of Local Self-Government, 13(2), pp. 129-160,

https://doi.org/10.4335/13.2.129-160(2015)

OAtes, W. E. (1991). On the nature and measurement of fiscal illusion: a survey. [A fiskális illúzió jellegéről és méréséről: egy felmérés.] In: W. E. Oates (szerk.) Studies in Fiscal Federalism. [Fiskális föderalizmus tanulmányok.] pp. 431-448

Ott, K., Bronić, M., Petrušić, M. (2014). Budget transparency of Croatian counties, cities and municipalities in 2013/2014 [A horvát megyék, városok és települések költségvetési átláthatósága 2013/2014-ben], Hirlevél, 87.

https://doi.org/10.3326/nle.2014.87

Peisakhin, L., Pinto, P. (2010). Is transparency an effective anti-corruption strategy? Evidence from a field experiment in India. [Az átláthatóság eredményes korrupcióellenes stratégia? Egy Indiában végzett gyakorlati kísérletből származó bizonyítékok.] Regulation \& Governance, 4(3), pp. 261-280,

https://doi.org/10.1111/j.1748-5991.2010.01081.x

Perez, C. C., Rodriguez Bolivar, M. P., Lopez-Hernandez, A. M. (2008). e-Government Process and Incentives for Online Public Financial Information. $[\mathrm{Az}$ online nyilvános pénzügyi információkhoz kapcsolódó e-kormányzati folya- matok és ösztönzők.] Online Information Review, 32(3), pp. 379-400,

https://doi.org/10.1108/14684520810889682

Pina, V., Torres, L., Royo, S. (2010). Is E-Government Promoting Convergence Towards More Accountable Local Governments? [Az e-kormányzat előmozdítja az elszámoltathatóbb helyi önkormányzatok irányába történő elmozdulást?] International Public Management Journal, 13(4). pp. 350-380,

https://doi.org/10.1080/10967494.2010.524834

Pintea, M.-O., Асhim, S. A., Lacătuş, V. (2013). Transparency of local budgets in the NordWest Region of Romania. [A helyi költségvetések átláthatósága Románia észak-nyugati régiójában.] A Nagyváradi Egyetem évkönyve. Economic Sciences, [Gazdaságtudományok.] 1., pp. 931-941, http://steconomiceuoradea.ro/anale/volume/2013/ n1/098.pdf.

Pintea, M.-O. (2014). Transparency of local budgets in the Center Region of Romania. [A helyi költségvetések átláthatósága Románia központi régiójában.] Review of Economic Studies and Research Virgil, Madgearu, pp. 81-96

Piotrowski, S. J., Van Ryzin, G. G. (2007). Citizen Attitudes Toward Transparency in Local Government. [A helyi önkormányzatok átláthatóságára irányuló állampolgári attitüdök.] The American Review of Public Administration, 37(3), pp. 306-323, https://doi.org/10.1177/0275074006296777

Powell, W. W., P. J. DiMaggio, szerk. (1991). The New Institutionalism in Organizational Analysis. [Új institucionalizmus a szervezeti elemzésben.] University of Chicago Press, Chicago, https://doi.org/10.7208/chicago/9780226185941.001.0001

Rodríguez-Bolívar, M. P., Alcaide-Muñoz, L., López Hernández, A. M. (2013). Determinants of Financial Transparency in Local Government. [A 
pénzügyi átláthatóságot meghatározó tényezők a helyi önkormányzatban.] International Public Management Journal, 16(4), pp. 557-602, https://doi.org/10.1080/10967494.2013.849169

Scott, W. R. (1987). The Adolescence of Institutional Theory. [Az intézményi elmélet serdülőkora.] Administrative Science Quarterly, 32(4)., pp. 493-511, https://doi.org/10.2307/2392880

Sedminradská, L. (2015). Budget Transparency in Czech Local Government. [Költségvetési átláthatóság a cseh helyi önkormányzatokban.] Procedia Economics and Finance, 25., pp. 598-606, https://doi.org/10.1016/S2212-5671(15)00774-1

Sedminradská, L., Haas, J. (2013). Budget Transparency and Fiscal Performance: Do Open Budgets Matter? [Költségvetési átláthatóság és fiskális teljesítmény: számítanak a nyitott költségvetések?] ACTA VŠFS. 7(2), pp. 109-122

Serrano-Cinca, C., Rueda-Tomas, M., Portillo-Tarragona, P. (2008). Factors Influencing E-disclosure in Local Public Administrations. [A helyi közigazgatásokban az elektronikus közzétételt befolyásoló tényezők.] 2008-03. munkadokumentum. Facultad de Ciencias Economicas y Empresarialed: Universidad de Zaragoza, (2017. január 22.) http://www.dteconz.unizar.es/DT200803.pdf

Sol, D. A. del. (2013). The institutional, economic and social determinants of local government transparency. [A helyi önkormányzatok átláthatóságát meghatározó intézményi, gazdasági and társadalmi tényezők.] Journal of Economic Policy Reform, 16(1), pp. 90-107, https://doi.org/10.1080/17487870.2012.759422

Styles, A., Tennyson, M. (2007). The Accessibility of Financial Reporting of U.S. Municipalities on the Internet. [USA-beli önkormányzatok pénzügyi beszámolóinak hozzáférhe- tősége az interneten.] Journal of Public Budgeting, Accounting \& Financial Management, 19(1), pp. 56-92, https://doi.org/10.1108/jpbafm-19-01-2007-b003

Suchman, M. C. (1995). Managing Legitimacy: Strategic and Institutional Approaches. [A legitimitás kezelése: stratégiai és intézményi megközelítésmódok.] Academy of Management Review, 20(3), pp. 571-610,

https://doi.org/10.5465/amr.1995.9508080331

Tekeng, Y. M. T., Sharaf, M. F. (2015). Fiscal Transparency, Measurement and Determinants: Evidence from 27 Developing Countries. [Átláthatóság, mérés és meghatározó tényezők: 27 fejlődő országból származó bizonyítékok.] Journal of Economics and Political Economy, 2(1), pp. 69-91

Weber, M. (1978). The types of Legitimate Domination. [A törvényes uralom típusai.] In: G. Roth és C. Wittich, (szerk.) Economy and Society. [Gazdaság és társadalom.] Berkeley: University of California Press, pp. 212-254

Wehner, J., De Renzio, P. (2013). Citizens, Legislators, and Executive Disclosure: The Political Determinants of Fiscal Transparency. [Állampolgárok, jogalkotók és végrehajtói közzététel: a fiskális átláthatóság politikai meghatározó tényezői.] World Development, 41., pp. 96-108, https://doi.org/10.1016/j.worlddev.2012.06.005

Določitev koeficientov razvitosti občin. (n.d.). Letöltve 2017. február 23-án, a következő weboldalról: http://www.mf.gov.si/si/delovna_podrocja/ lokalne_skupnosti/izracuni/dolocitev_koeficientov_ razvitosti_obcin/za_leti_2016_in_2017/

IBP (2013). Subnational Open Budget Survey Metodology. [Szubnacionális nyitott költségvetési felmérési módszertan.] http://internationalbudget. org/wp-content/uploads/SN-OBS_Methodology_ final020514.pdf 
IMF (2007). Manual on fiscal transparency [A fiskális átláthatóság kézikönyve] (2007). Washington DC: Nemzetközi Valutaalap, http://www.imf. org/external/np/pp/2007/eng/101907m.pdf [Utolsó hozzáférés: 2017. június 10.]

IMF (2014). The Fiscal Transparency Code. [Fiskális átláthatósági kódex.] http://blog-pfm.imf.org/ files/ft-code.pdf

Közkiadások és pénzügyi elszámoltathatóság (Public Expenditure and Financial Accountability) keretrendszer. https://pefa.org/content/pefa-frame work

OECD (2001). Az OECD költségvetési átláthatósággal kapcsolatos legjobb gyakorlatai. Párizs: Gazdasági Együttműködési és Fejlesztési Szervezet (OECD), http://www.oecd.org/dataoecd/33/13/1905258.pdf

Transparency of Local Budgets in the North-West Region of Romania. [A helyi költségvetések átláthatósága Románia észak-nyugati régiójában.] (2013). A Közgazdasági Tanszék évkönyve, (1), p. 931 